LBNL - 44749

\title{
The LBNL Water Heater Retail Price Database
}

\author{
Alex Lekov, Julie Glover, and Jim Lutz \\ Energy Analysis Department, Lawrence Berkeley National Laboratory
}

\begin{abstract}
Lawrence Berkeley National Laboratory developed the LBNL Water Heater Price Database to compile and organize information used in the revision of U.S. energy efficiency standards for water heaters. The Database contains all major components that contribute to the consumer cost of water heaters, including basic retail prices, sales taxes, installation costs, and any associated fees. In addition, the Database provides manufacturing data on the features and design characteristics of more than 1100 different water heater models. Data contained in the Database were collected over a two-year period from 1997 to 1999.
\end{abstract}

\section{PURPOSE}

Federal law sets energy conservation standards for various products and authorizes the U.S. Department of Energy to create or amend energy efficiency standards for major household appliances. Any new or amended standard must be designed to achieve "the maximum improvement in energy efficiency" that is, according to National Appliance Energy Conservation Act of 1987, "technologically feasible and economically justified." In determining economic justification for water heater standards, a number of different factors are considered, including the economic impact on consumers. This report discusses the development of a database of residential water heater prices and costs used by LBNL in the current revision of efficiency standards for residential water heaters. The report covers the methodology, database structure, and data collection issues; tables and graphs provide descriptive statistics of the gathered data. The Database is a completed product and is posted on the U.S. Department of Energy's web site and is available for public use. <http://www.eren.doe.gov/buildings/codes_standards/applbrf/ whdbver2.mdb $>1$

The LBNL Water Heater Price Database, the first such attempt to comprehensively list residential water heater retail prices and installation costs, provides information about the U.S. water heater market during the period 1997-1999. It contains data on electric and gas-fired water heaters covered by the 1987 Act, i.e., electric water heaters with rated volumes between 20 and 80 gallons and gas-fired water heaters with rated energy inputs of less than $75,000 \mathrm{Btu} / \mathrm{hr}$. Limited information on oil-fired water heaters is also included.

The energy efficiency standards analysis uses price information from the Database to estimate the impact that proposed standards would have on water heater 
retail prices, because changes in regulations can lead to increased costs that are passed on from manufacturers to retailers and consumers in the form of higher prices. The Database supports two major branches of the standards development. First, the data were used to develop median retail prices and installation costs for all sizes of analyzed water heaters. This information, together with the water heater manufacturing costs, was used in the LBNL engineering analysis to determine manufacturer cost-to-retail price markup. Second, the distributions of retail prices and installation costs were used in the LBNL life-cycle cost analysis. Detailed information about the engineering and the life-cycle cost analyses for the revised standards are included in the DOE Technical Support Document: Energy Efficiency Standards for Consumer Products: Residential Water Heaters.

\section{DATABASE DEVELOPMENT}

\subsection{Background}

In 1997, LBNL, with assistance from Pacific Northwest National Laboratory (PNNL) and the Arthur D. Little, Inc. (ADL) began to develop a database of product specifications (such as different design characteristics), retail prices, and installation costs for residential water heaters currently for sale in the U.S. A preliminary version of the Database was completed in 1998. Subsequent changes, made in response to comments received at the DOE Water Heater Workshop held in November $1998{ }^{3}$, led to a second version. The data collection was completed in 1999.

\subsection{Collection Methods}

The data collection effort began with the identification of water heater sales networks. The two major distribution channels for water heaters are plumbing wholesalers (e.g., Ferguson, Noland, etc.) and large retailers such as Home Depot and Sears. Manufacturers' sales are approximately equally divided between the two channels and most manufacturers sell to both; however, certain manufacturers, such as A.O. Smith and Bradford White, distribute only through wholesalers. Competition has led to a near equalization of prices between the two channels. In 1996, approximately 4.2 million water heaters were sold through plumbing wholesalers and 4.7 million were sold through

retailers. ${ }^{4}$ Installers buy from either source, although water heaters sold for new housing construction are sold primarily through plumbing wholesalers. Standard electric and gas water heaters are sold with relatively small markups. Manufacturer, distributor, and installer markups are summarized in Figure 1. 


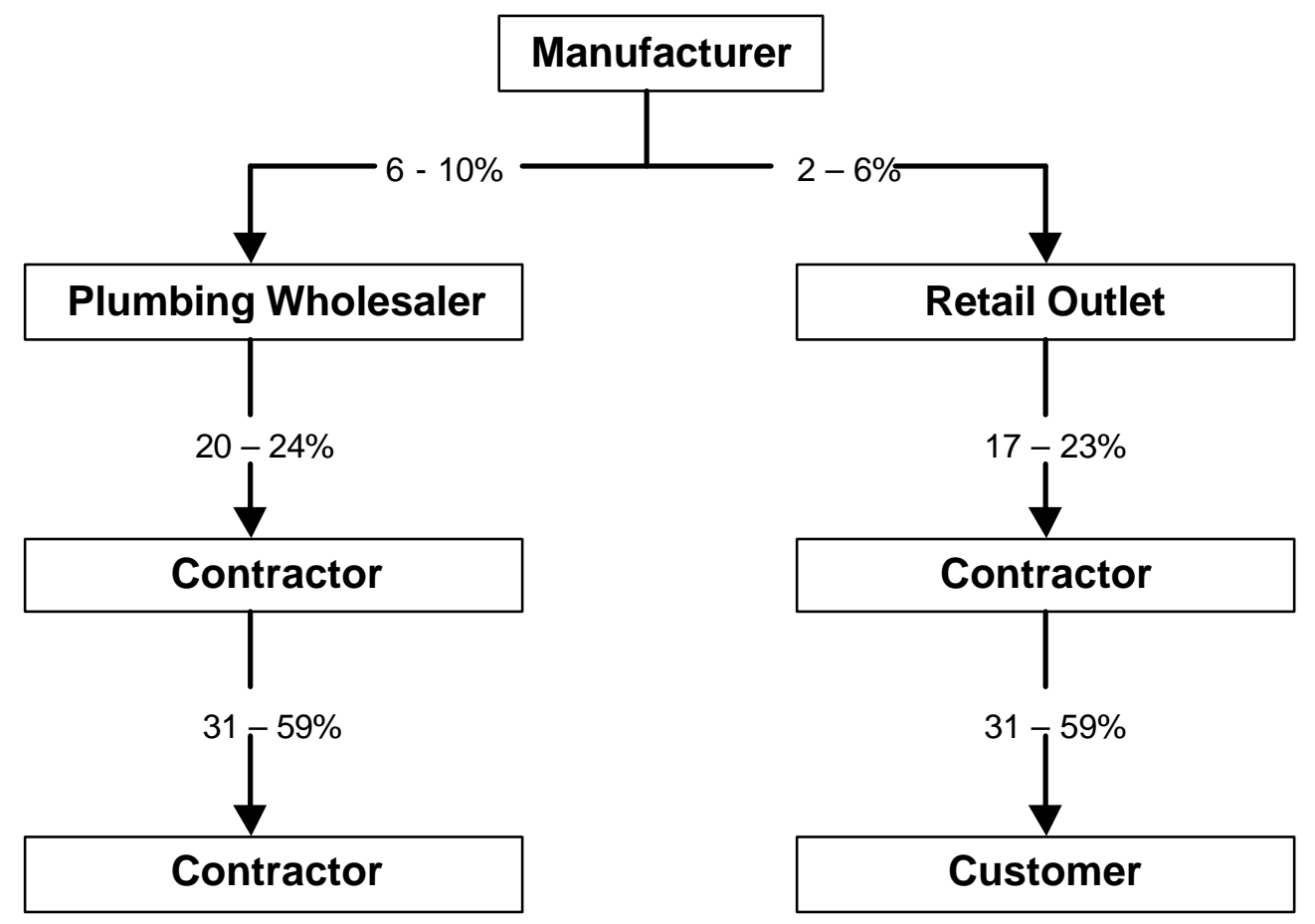

Figure 1 Typical Markups for Residential Water Heaters

Source: Barbour, C.E. et al., Market Disposition of High-Efficiency Water Heating Equipment, 1996.

The Database contains information from a wide variety of sources, including interviews with more than 130 contacts throughout the country. Information was gathered for more than 1,100 models, including retail prices, sales tax, installation and other related fees, and length of the manufacturer warranty. Detailed product specification information (i.e., certified energy factor, first-hour rating) was collected from manufacturer product literature, telephone calls to manufacturer representatives and technical information hotlines, and from Gas Appliance Manufacturers Association (GAMA) and California Energy Commission (CEC) directories. ${ }^{5,6}$ Information on oilfired water heaters was collected from interviews with approximately 25 oil equipment installers who buy water heaters from manufacturers and sell directly to consumers.

Definitions. Retail price, as reported in the Database, is defined as the consumer cost of the water heating equipment only. It is the price paid to a retail outlet or plumbing wholesaler by a consumer (homeowner or plumbing contractor). Discounted prices, such as for units on sale or sold in volume, were excluded from the data collection. Sales tax is the state, county, and/or local tax applied to the purchase price and is recorded separately. Installation, usually offered by independent contractors or directly by the retail outlet, is also accounted for separately, as are other fees such as for delivery, permits, parts, and removal of the old water heater. Manufacturer product specifications include water heater design characteristics (e.g., heat traps, electronic ignition) and performance, as measured by EF (energy factor). The specification data allows one to establish relationships between retail prices and specific water heater characteristics. 


\subsection{Database Data Quality}

The data were collected through interviews with various types of water heater vendors, e.g., large retailers, plumbing wholesalers, small suppliers, on-line sales, and utility representatives. Of this data, $80 \%$ of the price information was gathered from large retailers and plumbing wholesalers, while the remaining $20 \%$ was collected from the other types of vendors listed. Every effort was made to identify and contact as many sources as possible throughout the country. In general, portions of the country with higher concentrations of population were canvassed more heavily. We compared the geographical distribution of the data sources to the regional populations of the U.S. to insure an adequate representation. Where regions were underrepresented, additional contacts were made.

As a quality control measure, water heater model information was checked against the GAMA and CEC directories of certified water heaters and an extensive LBNL library of current manufacturer product literature. Missing information captured in this process included performance characteristics such as EF and design characteristics such as heat trap availability, insulation thickness, etc. Some data identified as outliers were checked for accuracy using additional sources, including manufacturer technical support hotlines, industry experts, and component manufacturers.

\subsection{Database Structure}

The Water Heater Price Database was developed using the Microsoft Access relational database application. A relational database provides the user with the means of sorting and extracting information from its tables through the use of queries; queries help isolate and view particular items of interest and can be used to display, in this database for example, the prices of water heaters that have certain efficiency ratings, fuel types, and/or design characteristics. The three principal data tables in the Database are described below; Tables A-1, A-2, and A-3 in Appendix A list the variable names and definitions used in the tables. Appendix B presents important characteristics and breakdowns of the data contained in the Database.

The Source Information Table contains information about the sales source. It includes the state in which the store is located and the sales tax applied at the location. The date of contact is provided as well as information about whether the data were collected by telephone or from the web. A numeric "store code" has been assigned to each sales source to ensure confidentiality of the source identity. The store code is used as a linking variable between the Source Information Table and the Price Information Table and provides reference to 1031 instances of water heater models in stock and sold by the various sales sources.

The Price Information Table contains information on water heater retail prices and lists any fees that might accompany a water heater purchase (installation fee, delivery, permit, parts, and removal fees), but not sales tax. Since the warranty period 
directly affects retail prices of water heaters, the length of the store warranty is included in this table. It should be noted that the store warranty often differs from the warranty offered by the manufacturer. The water heater model number is also included in this table; it is the linking variable between the Price Information Table and the Model Information Table.

The Model Information Table includes detailed information on water heater features such as fuel type, rated volume, rated input, first hour rating, energy efficiency rating, dimensions, various design options, and length of manufacturer warranty. The manufacturer names, brand names, and series names are also included. This table records the primary source of the data and also provides information about whether or not the water heater is covered by state or federal regulations. The review date indicates the most recent date of update of the record. The Model Information Table displays water heater characteristics for 1121 unique manufacturers' units, whether on the market or found solely in the literature.

Two additional tables, Introduction to Database and Description of Database Fields, do not include water heater-specific data but supplement the data tables with descriptive information. The Introduction to Database table describes the purpose and the structure of the entire Database and the Description of Database Fields table defines the variables used throughout the Database.

\section{WATER HEATER COST DATA SUMMARY}

The price information in the Water Heater Price Database distinguishes it from other collections. The retail prices and installation costs in the Price Information Table are grouped by fuel type and size (rated volume) corresponding to the categories used by GAMA to report shipments. ${ }^{5}$ Residential electric water heaters are manufactured most commonly in sizes ranging from 30 to 80 gallons, and have been grouped into five size categories; gas-fired water heaters come in sizes ranging from 30 to 75 gallons, and are grouped into four categories. Table 1 lists the categories and shows how the groupings were made. These categories are used throughout the discussions below.

Table 1 Size Categories

\begin{tabular}{|l|c|}
\hline Fuel Type & $\begin{array}{c}\text { Category } \\
\text { gal }\end{array}$ \\
\hline Electric & 30 \\
\cline { 2 - 2 } & 40 \\
\cline { 2 - 2 } & 50 \\
\cline { 2 - 2 } & 65 \\
\cline { 2 - 2 } & 80 \\
\hline Gas-Fired & 30 \\
\cline { 2 - 2 } & 40 \\
\cline { 2 - 2 } & 50 \\
\cline { 2 - 2 } & 75 \\
\hline
\end{tabular}


In addition, the most commonly available unit for each fuel type was identified. These units represent the most common size water heaters, 50-gallon rated volume electric water heaters, 40-gallon rated volume gas-fired water heaters, and 32-gallon rated volume oil-fired water heaters. They have efficiency ratings equal to the minimum allowed by existing energy efficiency standards and come with 6-year warranties. The gas-fired and oil-fired water heater models have 1 in. $(2.5 \mathrm{~cm})$ of polyurethane foam insulation and the electric model has up to 1.5 in. $(3.75 \mathrm{~cm})$ insulation. The general characteristics of these models are shown in Table 2.

Table 2 Characteristics of the Most Commonly Available Models

\begin{tabular}{|l|c|c|c|}
\hline & Electric & Gas-Fired & Oil-Fired \\
\hline Rated Volume & 50 gal. & 40 gal. & 32 gal. \\
Rated Input & 4,500 Watts & $40,000 \mathrm{Btu} / \mathrm{hr}$ & $90,000 \mathrm{Btu} / \mathrm{hr}$ \\
Energy Factor & 0.86 & 0.54 & 0.53 \\
Recovery Efficiency & $98 \%$ & $76 \%$ & $75 \%$ \\
Insulation Thickness & $1.5 \mathrm{in}$. & $1 \mathrm{in.}$ & $1 \mathrm{in.}$ \\
\hline
\end{tabular}

\subsection{Retail Prices}

The Database contains retail prices for all standard size water heaters. As expected, the most common size models are more heavily represented than less common ones. Figure 2 shows the number of models for each size electric water heater for which there is retail price data in the Database. Figure 3 presents the same data for gas-fired water heaters. As the figure shows, the most common electric water heater, the 50-gallon model, is found in 97 records. For gas-fired water heaters, there are 98 records for the 40gallon model.

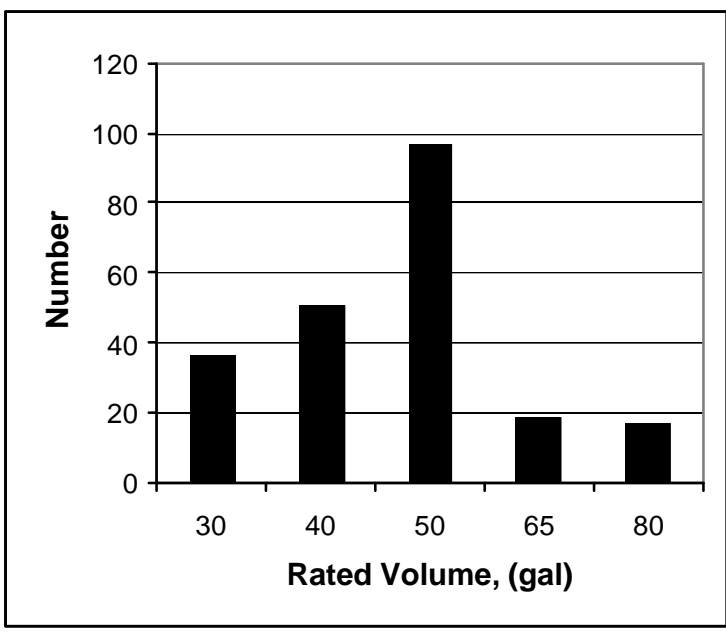

Figure 2 Number of Electric Water Heater Models in Database

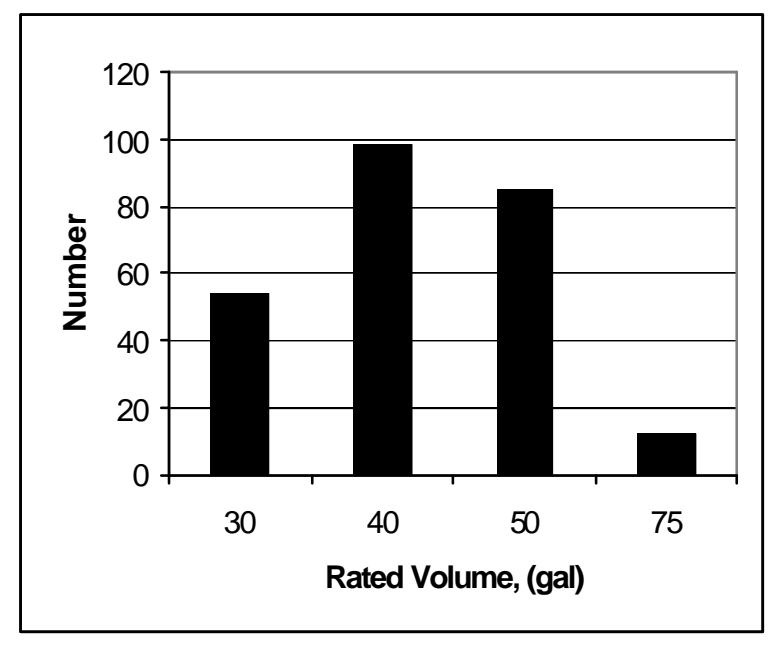

Figure 3 Number of Gas-Fired Water Heater Models in Database

The range of retail prices for each size water heater can be determined by grouping retail price data by tank size. The retail prices for the most common water 
heaters of all sizes contained in the Database are shown in Figure 4 for electric water heaters and in Figure 5 for gas-fired water heaters. The mid-values represent the median reported retail prices. The figures also show the minimum and maximum values. For example, the median retail price for a 50 -gallon electric water heater is $\$ 182$, the minimum reported price is $\$ 128$, and the maximum is $\$ 385$. In the case of gas-fired water heaters, the median retail price for the 40 -gallon water heater is $\$ 163$, with a minimum of $\$ 115$ and a maximum of $\$ 353$. The median retail price for oil-fired water heaters is $\$ 446$, with a minimum of $\$ 285$ and a maximum of $\$ 700$. These retail prices do not include sales tax.

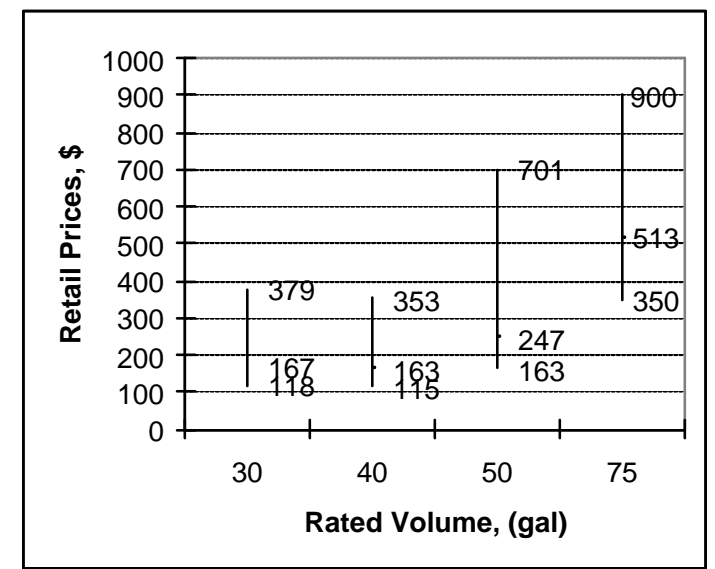

Figure 4 Retail Price Ranges: Electric Water Heaters

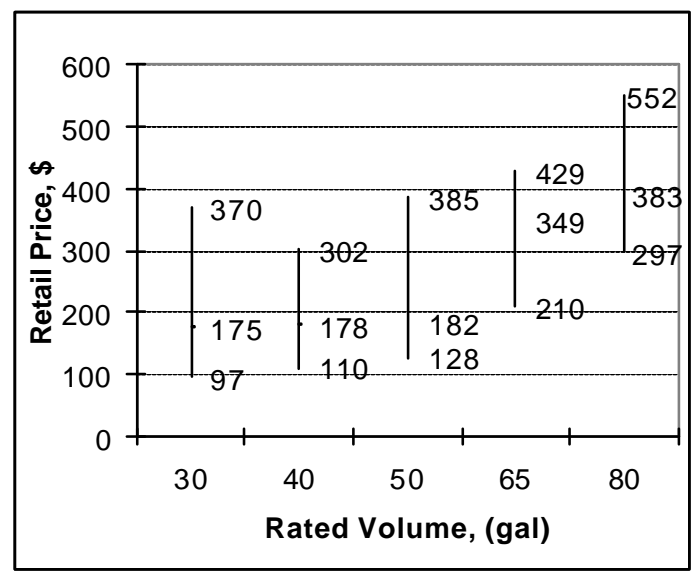

Figure 5 Retail Price Ranges: Gas-Fired Water Heaters

As shown in Figures 2 and 3, there are substantial differences in the number of responses for the various standard sizes; this is consistent with the fact that certain models (i.e., 40gallon and 50-gallon models) are sold in significantly larger quantities and in more places than others. It is possible to compare the distribution of water heater sizes in the Database to actual shipment data provided by GAMA. ${ }^{8}$ Figure 6 shows the fraction of electric water heaters by rated volume in the Database (from 1998) against the GAMAreported shipments for 1995. Figure 7 shows the same for gas-fired water heaters. The figures show that the numbers more or less track each other (although for electric water heaters there is relatively less information on the smaller sizes in the Database, as compared to the proportion of 1995 shipments). Note that there is a 3-year gap between the latest available GAMA data and the information in the Database; it is not expected that the size distributions have changed much in the intervening years. 


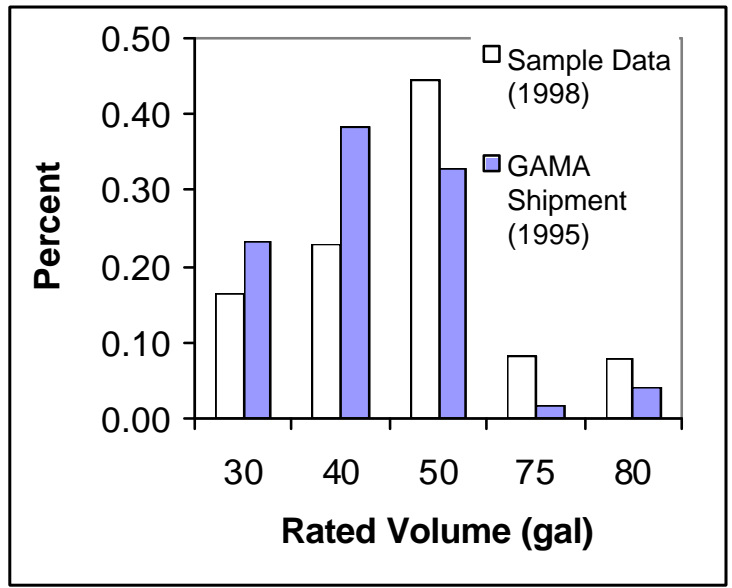

Figure 6 Electric Water Heaters: Shipments vs Database Data

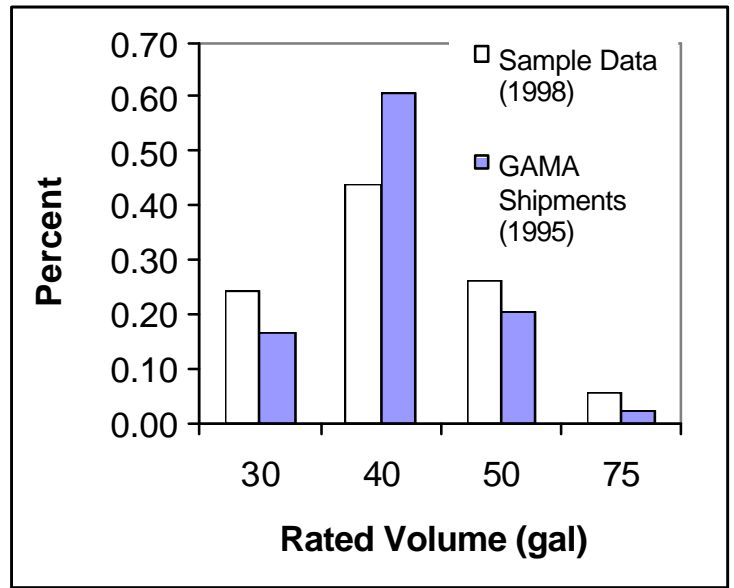

Figure 7 Gas-Fired Water Heaters: Shipments vs Database Data

\subsection{Installation Costs}

From the installation cost data in the Water Heater Price Database, one can develop ranges of installation costs for different size water heaters. Figure 8 shows the number of electric water heater retailer responses upon which the installation cost data are based. Figure 9 presents the same information for gas-fired water heaters. For example, the median installation cost for a 50-gallon electric water heater is based on 57 responses about installation costs; the median installation cost for the 40-gallon gas-fired water heater is based on 56 responses.

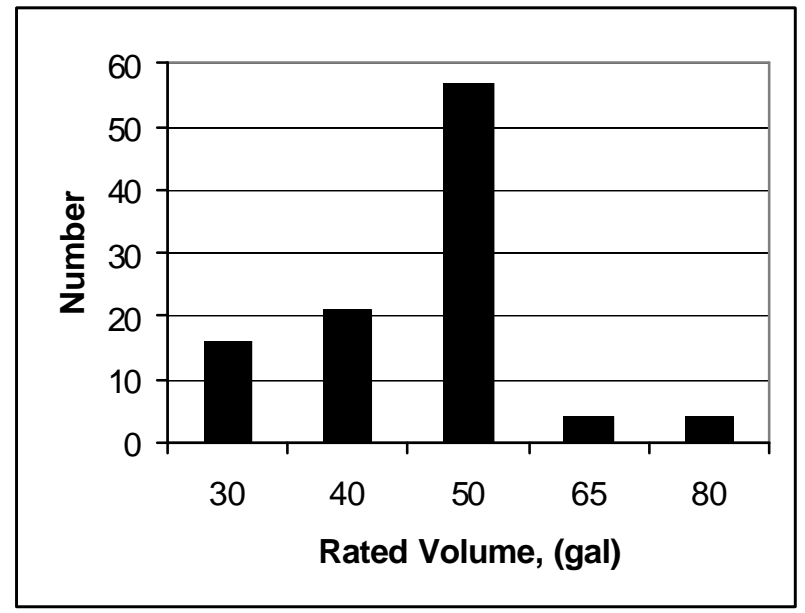

Figure 8 Number of Electric Water Heater Models with Installation Costs

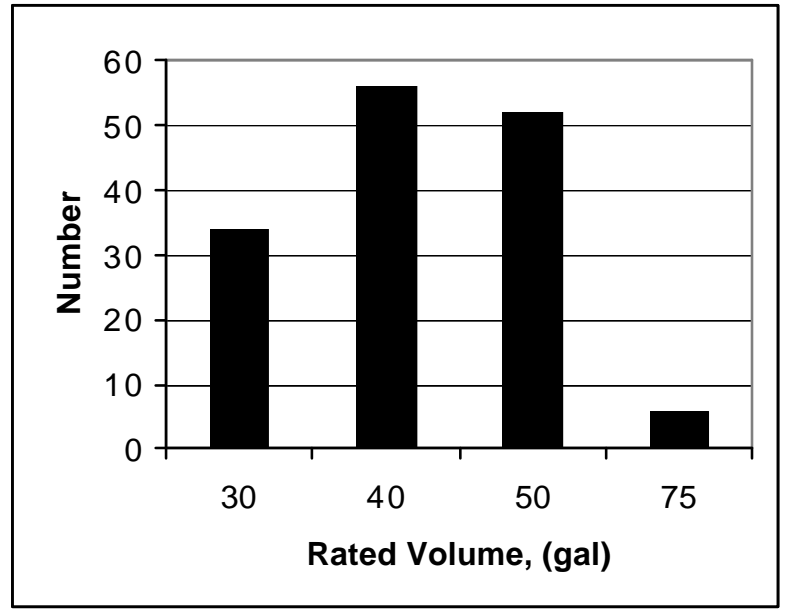

Figure 9 Number of Gas-Fired Water Heater Models with Installation Costs 
The installation costs for water heaters of all sizes are shown in Figure 10 for electric water heaters and in Figure 11 for gas-fired water heaters. The mid-values represent the median installation cost for each water heater size. The figures also show the minimum and maximum values from the collected data. For example, the median installation cost for a 50-gallon electric water heater is $\$ 155$, with the minimum reported to be as little as $\$ 65$ and the maximum as high as $\$ 269$. The relatively narrow cost range for 65-gallon electric water heaters is primarily the result of the small number of responses for this particular tank size (see Figure 8). In the case of gas-fired water heaters, the median installation cost for a 40 -gallon water heater is $\$ 159$, with a minimum of $\$ 65$ and a maximum of $\$ 292$.

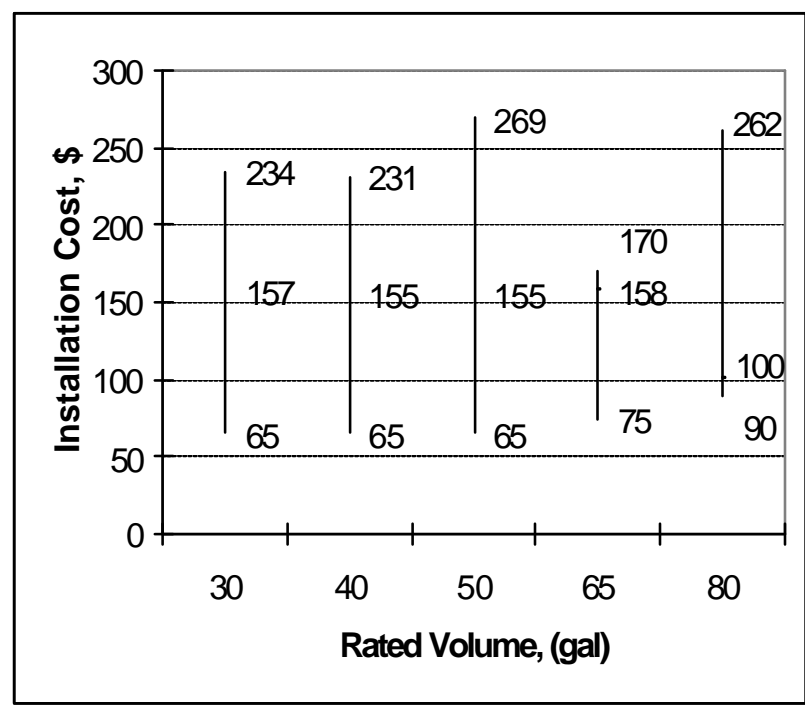

Figure 10 Installation Cost Ranges: Electric Water Heaters

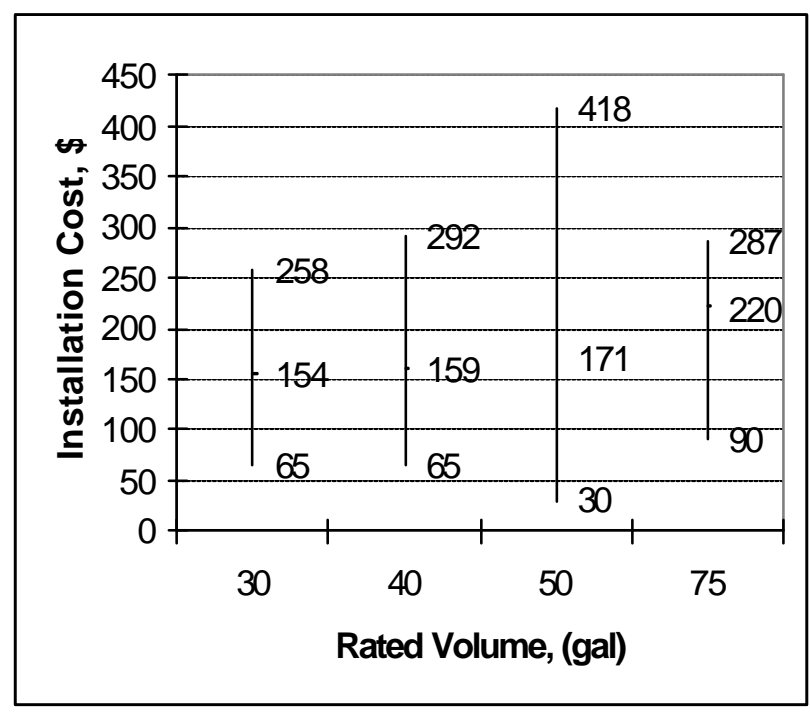

Figure 11 Installation Cost Ranges: Gas-Fired Water Heaters

In addition, the median installation cost for oil-fired water heaters was determined to be $\$ 491$, with a minimum of $\$ 210$ and a maximum of $\$ 500$. This is the cost for a new construction installation of a water heater without a burner. New construction installation costs for both tank and burner vary from $\$ 550$ to a high of $\$ 950$. 


\section{PRINCIPAL CHARACTERISTICS OF THE DATABASE}

\subsection{Use in Water Heater Standards Development}

The Water Heater Price Database serves as the primary resource for price information in DOE's current revision of the water heater energy efficiency standards. A major use of the water heater retail price data is to determine the markup from the manufacturing cost to the price paid by consumers. Markup is defined here the amount added to the manufacturer's cost of the water heater to cover overhead and profit by the manufacturer, wholesaler, or retailer. This markup is important for the evaluation of the impact on consumers of possible future design changes that aim to improve water heater efficiency. In addition, the collection and analysis of fees associated with installation, delivery, parts, permits, etc., for different size water heaters allows for an assessment of other consumer costs for installing water heaters.

Another important factor in the development of the markup is the manufacturer warranty period. The warranty period is directly associated with the water heater retail price. For purposes of determining markup, water heaters warrantied for either five or six years are generally considered to be the most commonly sold water heater models. Note that a longer warranty period, in addition to a higher price, may indicate the presence of features not usually found in the most commonly sold models. One-year warranties are also offered in special cases.

Sales tax information is important to the development of the total cost of the water heater to the consumer. Table 3 shows the distribution of sales taxes for the stores listed in the Price Information Table of the Database. Note that in some cases there are several different sales taxes for the same state due to differences at the local county or city level. 
Table $3 \quad$ Sales Taxes

\begin{tabular}{|l|l|l|l|l|l|l|l|l|l|l|}
\hline $\begin{array}{l}\text { Store } \\
\text { State }\end{array}$ & $\begin{array}{c}\text { Sales Tax } \\
\mathbf{\%}\end{array}$ & $\begin{array}{l}\text { Store } \\
\text { State }\end{array}$ & $\begin{array}{c}\text { Sales Tax } \\
\mathbf{\%}\end{array}$ & $\begin{array}{l}\text { Store } \\
\text { State }\end{array}$ & $\begin{array}{c}\text { Sales Tax } \\
\mathbf{\%}\end{array}$ & $\begin{array}{l}\text { Store } \\
\text { State }\end{array}$ & $\begin{array}{c}\text { Sales Tax } \\
\text { \% }\end{array}$ \\
\hline AK & 0.00 & & IA & 6.00 & & NC & 6.00 & & OR & 0.00 \\
\hline AR & 6.13 & & ID & 5.00 & & NE & 5.50 & & PA & 6.00 \\
\hline AZ & 4.30 & & IL & 6.25 & & NJ & 3.00 & & SD & 0.00 \\
\hline AZ & 6.80 & & IL & 8.75 & & NJ & 6.00 & & SD & 6.00 \\
\hline CA & 7.50 & & IN & 5.00 & & NM & 5.81 & & TN & 8.25 \\
\hline CA & 7.75 & & KS & 6.88 & & NV & 7.00 & & TX & 7.87 \\
\hline CA & 8.25 & & KY & 6.00 & & NY & 6.75 & & TX & 8.25 \\
\hline CO & 7.30 & & LA & 9.00 & & NY & 7.00 & & UT & 6.25 \\
\hline FL & 6.00 & & MA & 5.00 & & NY & 8.25 & & VA & 4.50 \\
\hline FL & 6.50 & & MI & 6.00 & & NY & 8.50 & & VA & 4.75 \\
\hline FL & 6.75 & & MN & 7.00 & & OH & 5.75 & & WA & 7.80 \\
\hline GA & 5.00 & & MO & 6.72 & & OH & 7.00 & & WA & 8.00 \\
\hline GA & 6.00 & & MS & 7.00 & & OK & 6.50 & & WA & 8.60 \\
\hline GA & 7.00 & & MT & 0.00 & & OK & 8.38 & & WI & 5.50 \\
\hline & & & & & & & & WV & 6.00 \\
\hline & & & & & & & & \\
\hline
\end{tabular}

\subsection{Water Heater Fuel Type Representation}

There are three major residential water heater product classes targeted in this data collection. These product classes are distinguished by fuel type (electric, gas, and oil). Although all fuel types are represented in the Database, the data focus on electric and natural gas-fired water heaters. The number of reported oil-fired units (41) is very small. Limited data were collected as well for liquified petroleum gas (LPG) fueled water heaters. Within each product class, the most common models comprise a major fraction of the total models in the Database. For example, $44 \%$ of the electric water heaters in the Database have a rated volume of 50 or 52 gallons and $45 \%$ of the gas-fired water heaters have a rated volume of 38 to 40 gallons. The data collected for oil-fired water heaters show that almost $90 \%$ of the residential installations are 32-gallon units.

The number of electric and gas-fired water heater models in the Database roughly correspond to the actual shipments of electric and gas-fired water heaters in the U.S. Approximately 4.2 million electric, 4.7 million natural gas (and LPG), and 40 thousand 
oil-fired water heaters are shipped each year. ${ }^{9}$ The number and percent of water heater models represented in the Database compared to the GAMA shipment data for the year 1995 are shown in Table 4.

Table 4 Water Heater Models in Database and Shipments by Fuel Type

\begin{tabular}{|l|c|c|c|c|}
\hline \multicolumn{1}{|c|}{ Fuel Type } & \multicolumn{2}{c|}{ Water Heater Models in Database } & \multicolumn{2}{c|}{ U.S. Water Heater Sales in 1995 } \\
\hline Number of Models & $\begin{array}{c}\text { Percentage } \\
\text { \% }\end{array}$ & $\begin{array}{c}\text { Number of Models } \\
\text { Millions }\end{array}$ & $\begin{array}{c}\text { Percentage } \\
\text { \% }\end{array}$ \\
\hline Electric & 477 & 47.1 & 4.16 & 46.9 \\
\hline Natural Gas* & 532 & 52.6 & 4.67 & 52.7 \\
\hline Oil & 3 & 0.3 & 0.04 & 0.5 \\
\hline
\end{tabular}

*Includes LPG models.

\subsection{Water Heater Distribution Representation}

Figure 12 displays the percentage breakdown of water heater sales by distributor type. The collected data show that the great majority of water heaters are sold either through retail outlets (e.g., Home Depot and Sears) or plumbing wholesalers (e.g., Ferguson and Noland). Small suppliers, who sell about 5\% of the total, are businesses that supply retailers and wholesalers with water heaters and occasionally sell to consumers. Web sales (i.e., through stores that have an on-line sales branch, such as W. W. Grainger, Inc., or Internet-only based stores) make up about $2 \%$ of the water heater models in the Database.

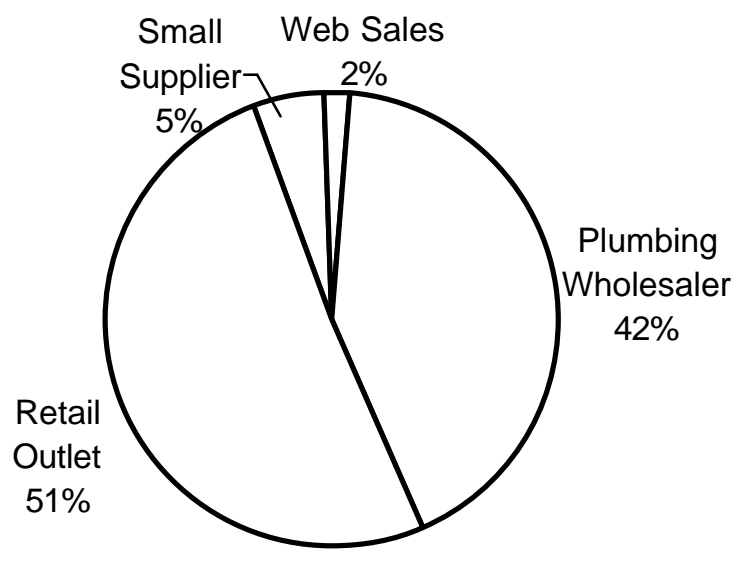

Figure 12 Water Heater Sales by Distributor Type 


\subsection{Water Heater Regional Representation}

Figure 13 compares the regional distribution of models in the Database with a breakdown of the U.S. population by region derived from U.S. Census data. ${ }^{10}$ The comparison shows that the regional distribution of water heaters in the Database reasonably reflects the distribution of the U.S. population. Note that for four regions (Pacific, Florida, South Atlantic, and East North Central), there is a pronounced difference between the water heater models listed in the Database and the regional population.

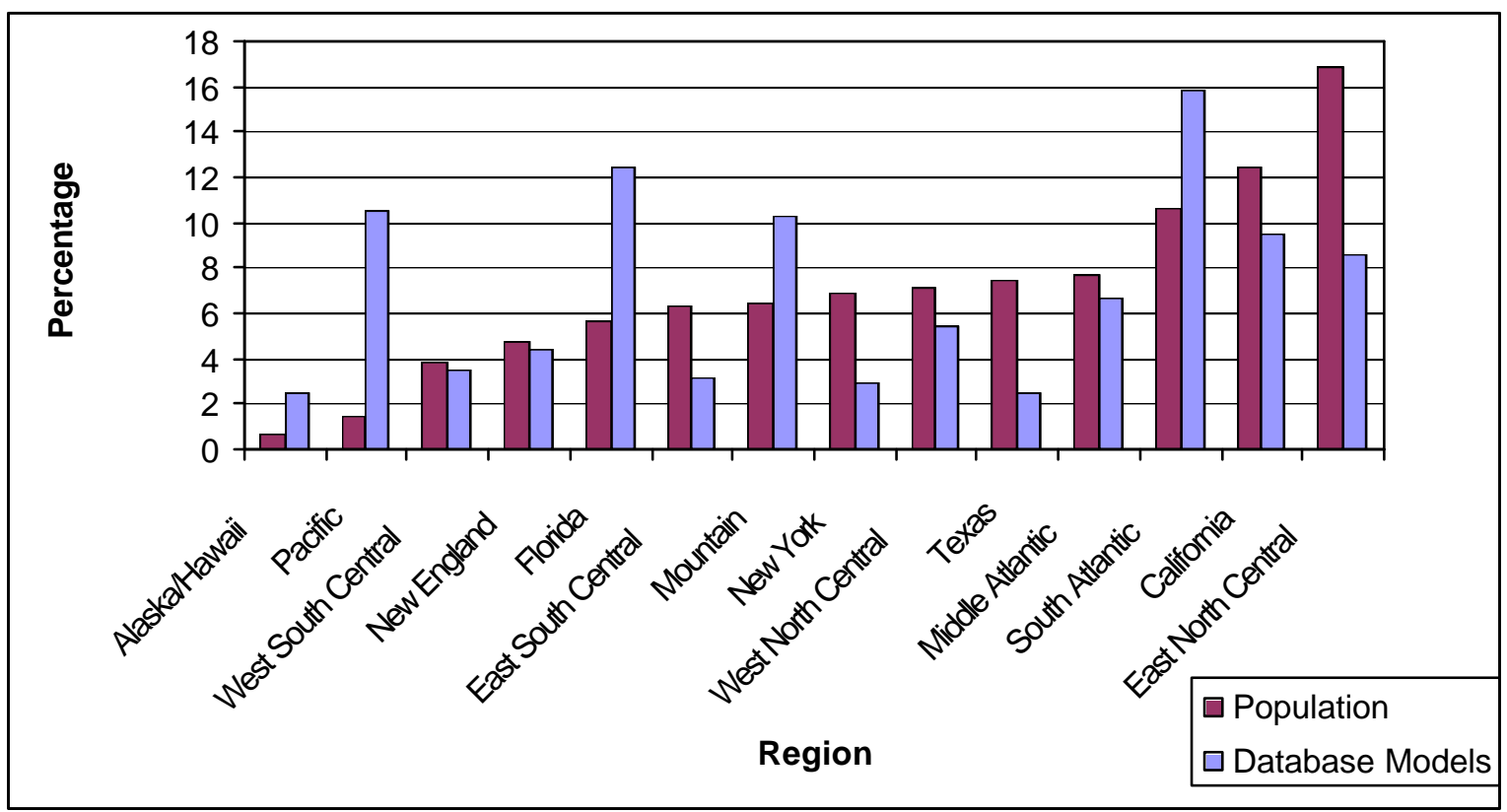

Figure 13 Population vs. Number of Water Heaters Models in the Water Heater Price Database 
Figure 14 displays a map of the locations of sources that provided price information listed in the Database.

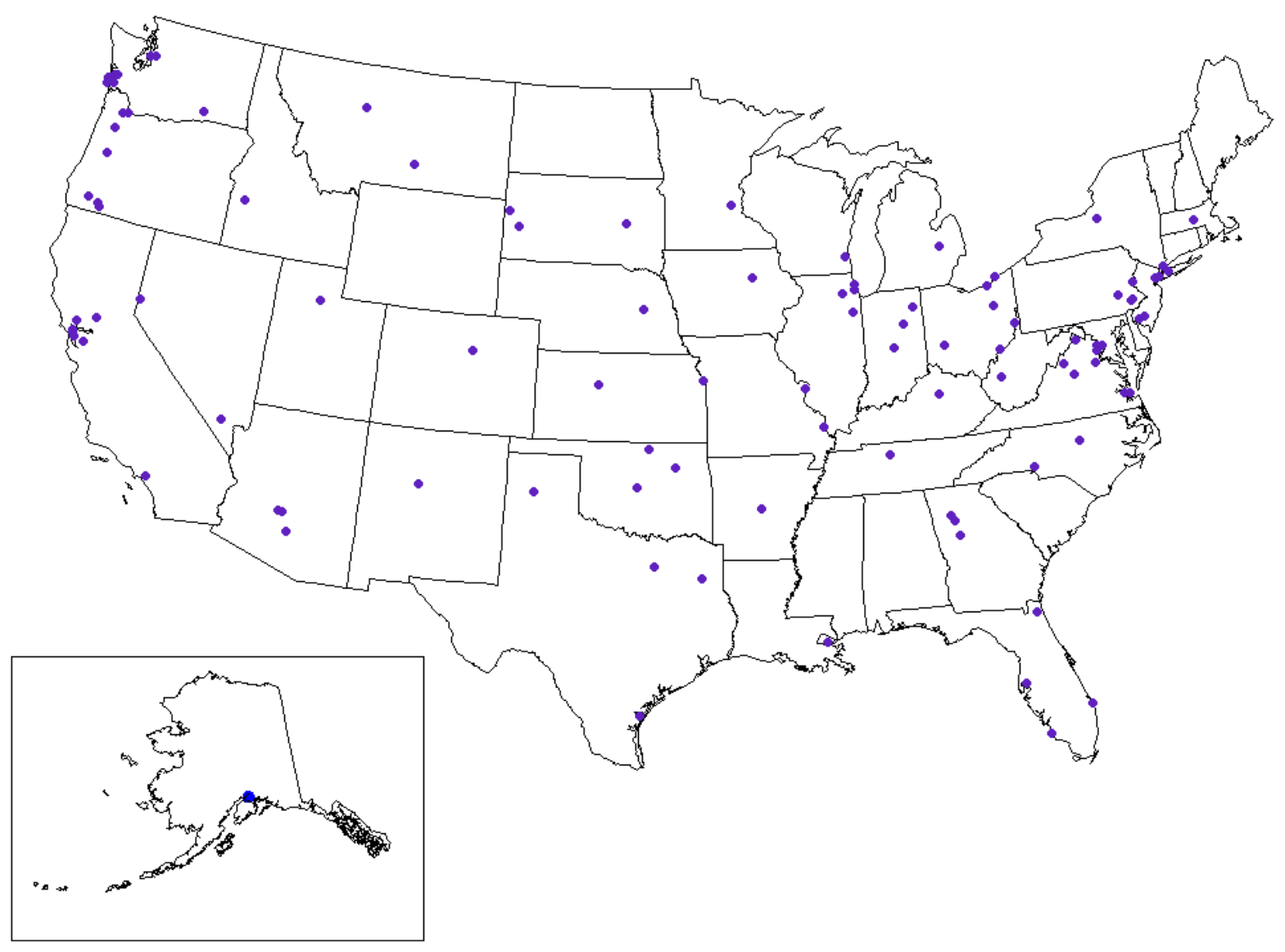

Figure 14 Store Locations Represented in Water Heater Price Database

\section{REMARKS}

The original intent of this project was to develop a collection of product specifications to be used in the engineering portion of the LBNL analysis of efficiency standards for residential water heaters. Gradually, the work was extended to include retail prices and installation costs. The price data became the centerpiece of the Database and was used extensively in the engineering and life-cycle cost analyses of the standards work. The function of the Database was extended even further as it became a reference tool for analysts, consultants, and policymakers interested in the relationships between water heater prices (and their associated costs), design improvements, and performance efficiency. 
Using simple queries, it is possible to obtain valuable market information on residential water heaters and to investigate how the different water heater design options are associated with retail prices and manufacturer warranties. It also allows one to look at the regional distribution and sales of different water heater models. User-generated charts graphically depict manufacturer market share, model distribution, and frequency of use of particular design options and characteristics of different models. Periodic updates and improvements to the Database will keep it current and useful as changes take place in the water heater retail market.

In summary, the Database provides a snapshot of retail prices and installation costs of residential water heaters during the 1997-1999 period. The data provides an overview of the water heater market and serves as a basis for estimating the cost of projected improvements in water heater design. Second, it documents the characteristics of water heaters manufactured by different companies, separated by fuel types, warranties, and design options (i.e., heat traps, electronic ignition, etc.). An examination of these characteristics leads to a better understanding of the water heater market. Third, the Database allows users to explore the relationships between price, design, and efficiency characteristics.

\section{Acknowledgments}

The authors wish to thank Terry Logee (DOE), Jim McMahon, Karen H. Olson, and Stuart Chaitkin (LBNL). We also want to thank our reviewers, Rich Brown, Jonathan Koomey, Robin Mitchell, and Mithra Moezzi, also of LBNL. This work was supported by the Office of Building Research and Standards of the U.S. Department of Energy under Contract No. DE-AC03-76SF00098. 


\section{REFERENCES}

1. U.S. Department of Energy-Office of Codes and Standards, Water Heater Price Database, 1999. (Last accessed June 24, 2000). <http://www.eren.doe.gov /buildings/codes_standards/applbrf/whdbver2.mdb>

2. U.S. Department of Energy-Office of Building Research and Standards, Technical Support Document: Energy Efficiency Standards for Consumer Products: Residential Water Heaters, 2000. Washington, DC. <http://erendev.nrel.gov /buildings/codes_standards/reports/waterheater/index.html>

3. U.S. Department of Energy, Workshop on Standards for Water Heaters, Transcript, November 9-10, 1998. Washington, DC.

4. Barbour, C. E., J. T. Dieckmann, and B. J. Nowicki, Market Disposition of HighEfficiency Water Heating Equipment, Final Report, November, 1996, Arthur D. Little, Inc. Prepared for the Office of Building Equipment, U.S. Department of Energy, Washington, DC. Report No. 46230.

5. Gas Appliance Manufacturers Association, Consumers' Directory of Certified Efficiency Ratings for Residential Heating and Water Heating Equipment, October, 1999. Cortland, NY. Prepared by Intertek Testing Services.

6. California Energy Commission, Directory of Certified Water Heaters, 1993. Sacramento, CA. Report No. P400-93-024.

7. Pacific Northwest National Laboratory, Telephone calls to residential oil-fired equipment dealers, April, 1998. Richland, WA.

8. Gas Appliance Manufacturers Association, Statistical Release, various years. Arlington, VA.

9. U.S. Department of Energy, Residential Energy Consumption Survey: Household Energy Consumption and Expenditures 1993, October, 1995, Energy Information Administration. Report No. DOE/EIA-0321(93).

10. U.S. Department of Commerce - Bureau of the Census-Population Estimates Branch, Intercensal Estimates of the Total Resident Population of States: 19801990, August, 1996. Washington, DC. 


\section{Appendix A}

\section{The Three Major Data Tables}

\begin{tabular}{|c|c|c|}
\hline Source Information Table & Price Information Table & Model Information Table \\
\hline $\begin{array}{c}\text { SeqNum } \\
\text { StoreCode } \\
\text { CallDate } \\
\text { Phone_Web } \\
\text { StoreState } \\
\end{array}$ & $\begin{array}{c}\text { SeqNum } \\
\text { StoreCode } \\
\text { StoreWarranty } \\
\text { RetailPrice } \\
\text { DeliveryFee } \\
\text { InstallFee } \\
\text { RemovalFee } \\
\text { PermitFee } \\
\text { PartFee } \\
\text { ModelNumber } \\
\end{array}$ & $\begin{array}{c}\text { ModelNumber } \\
\text { Manufacturer } \\
\text { Brand } \\
\text { Series } \\
\text { Baseline } \\
\text { Fuel } \\
\text { RatedVolume } \\
\text { RatedlnputGas } \\
\text { PowerLowerElem } \\
\text { RatedlnputOil } \\
\text { Shape } \\
\text { RE } \\
\text { EF } \\
\text { EF-ProdLit } \\
\text { FirstHrRating } \\
\text { Gallons90F } \\
\text { InsulThick } \\
\text { HeatTrap } \\
\text { HeatTrapOption } \\
\text { Height } \\
\text { Diameter } \\
\text { VentType } \\
\text { VentDiam } \\
\text { AnodeRod } \\
\text { DrainValve } \\
\text { Burner } \\
\text { Eleclgnition } \\
\text { Lining } \\
\text { Condensing } \\
\text { Weight } \\
\text { MfrWarranty } \\
\text { PartsWarranty } \\
\text { RegulatedProduct } \\
\text { GAMADirectory } \\
\text { CECDirectory } \\
\text { ProductLit } \\
\text { ReviewDate }\end{array}$ \\
\hline
\end{tabular}

Figure A-1 Map Showing Relationships Between the Three Data Tables 
Table A-1 Source Information Table: Variables and Their Definitions

\begin{tabular}{|c|c|}
\hline $\begin{array}{c}\text { Variable } \\
\text { Name } \\
\end{array}$ & Variable Definition \\
\hline SeqNum & Sequential number of records in the Source Information Table \\
\hline StoreCode & Number assigned to information source; references the Price Information Table \\
\hline CallDate & Date the store was contacted \\
\hline Phone_Web & Cost data collected from telephone conversation or web page \\
\hline StoreState & State in which store is located \\
\hline SalesTax & Sales tax at store location \\
\hline
\end{tabular}

Table A-2 Price Information Table: Variables and Their Definitions

\begin{tabular}{|l|l|}
\hline \multicolumn{1}{|c|}{$\begin{array}{c}\text { Variable } \\
\text { Name }\end{array}$} & \multicolumn{1}{c|}{ Variable Definition } \\
\hline $\begin{array}{l}\text { SeqNum } \\
\text { StoreCode }\end{array}$ & $\begin{array}{l}\text { Sequential number of records in the Price Information Table } \\
\text { Number assigned to information source; references the Source } \\
\text { Information Table } \\
\text { Warranty offered by store }\end{array}$ \\
$\begin{array}{l}\text { RetailPrice } \\
\text { DeliveryFee } \\
\text { Retail price reported by source (sales tax not included) } \\
\text { Fee reported by source for delivery of water heater (if delivery service } \\
\text { is available) }\end{array}$ \\
InstallFee & $\begin{array}{l}\text { Fee reported by source for installation of water heater (if installation service } \\
\text { is available) }\end{array}$ \\
RemovalFee & $\begin{array}{l}\text { Fee reported by source for removal of water heater (if removal service } \\
\text { is available) } \\
\text { Fee reported by source for permits (if permit fee is applicable) }\end{array}$ \\
PermitFee & $\begin{array}{l}\text { Fee reported by source for standard parts for installation (if part fee } \\
\text { is applicable) } \\
\text { Manufacturer's water heater model number, references the Model } \\
\text { Information Table }\end{array}$ \\
\hline
\end{tabular}


Table A-3 Model Information Table: Variables and Definitions

\begin{tabular}{|c|c|}
\hline Variable Name & Variable Definition \\
\hline ModelNumber & Model number specified by manufacturer, may be referenced in Price Information Table \\
\hline Manufacturer & Name of manufacturer \\
\hline Brand & Brand name of water heater \\
\hline Series & Series name of water heater \\
\hline Baseline & "T" (true) indicates baseline model \\
\hline Fuel & Water heater fuel type (natural gas, LPG, oil, or electricity) \\
\hline RatedVolume & Manufacturer's rated storage volume of the water heater (in gallons) \\
\hline RatedInputGas & Manufacturer's rated input in Btu/hr (Gas-fueled models only) \\
\hline PowerLowerElem & Nominal rating of lower element in $\mathrm{kW}$ (Electric models only) \\
\hline PowerUpperElem & Nominal rating of upper element in kW (Electric models only) \\
\hline RatedInputOil & Manufacturer's rated fuel input in gallons/hour (Oil models only) \\
\hline Shape & Shape of water heater jacket \\
\hline $\mathrm{RE}$ & "Recovery Efficiency", given in \% (Gas-fueled and oil-fueled models only) \\
\hline $\mathrm{EF}$ & "Energy Factor" reported by GAMA Directory and/or CEC Directory \\
\hline EF-ProdLit & "Energy Factor" reported by manufacturer in the product literature \\
\hline FirstHrRating & "First Hour Rating" is a measure of the water heater's ability to provide hot water in gallons \\
\hline Gallons90F & Gallon per hour recovery rate at a 90 degree $\mathrm{F}$ temperature rise \\
\hline InsulThick & Jacket insulation thickness, in inches \\
\hline HeatTrap & $\begin{array}{l}\text { "T" (true) indicates that the model comes with heat traps, "F" (false) indicates that the model } \\
\text { does not come with heat traps }\end{array}$ \\
\hline HeatTrapOption & "T" (true) indicates that the model can be optionally equipped with heat traps \\
\hline Height & Height of the water heater (from the bottom to the top of the jacket), in inches \\
\hline Diameter & Diameter of the water heater jacket, in inches \\
\hline VentType & Type of vent \\
\hline VentDiam & Vent diameter, in inches \\
\hline AnodeRod & Type, material, and/or position of the anode rod \\
\hline DrainValve & Material of the drain valve \\
\hline Burner & Type or material of the burner (Gas and Oil models only) \\
\hline ElecIgnition & $\begin{array}{l}\text { "T" (true) indicates that the model is equipped with electronic ignition, }>\text { blank }<\text { indicates that } \\
\text { the model is not equipped with electronic ignition (Gas-fueled models only) }\end{array}$ \\
\hline Lining & Type or material of water heater tank lining \\
\hline Condensing & $\begin{array}{l}\text { Indicates that the model is designed to condense water vapor in the flue gases (Gas-fueled } \\
\text { models only) }\end{array}$ \\
\hline Weight & Shipping weight of water heater, in pounds \\
\hline MfrWarranty & Warranty issued by the manufacturer \\
\hline PartsWarranty & Parts warranty issued by the manufacturer \\
\hline RegulatedProduct & Model is covered by NAECA \\
\hline GAMADirectory & Checked box $=$ listed in GAMA Directory \\
\hline CECDirectory & Checked box $=$ listed in CEC Directory \\
\hline ProductLit & $\begin{array}{l}\text { Number listed on manufacturer's product literature or catalog where model specification } \\
\text { information was found }\end{array}$ \\
\hline ReviewDate & Date of most recent review \\
\hline
\end{tabular}




\section{Appendix B}

\section{Characteristics / Breakdowns of Summary Data}

Appendix B summarizes the data contained in the Water Heater Price Database focusing on specific parameters and defining characteristics. Pie charts show percentage breakdowns of important characteristics, concentrating on models listed in the Price Information Table.

\section{B.1 Water Heaters by Rated Volume}

Rated volume is the rated storage size of the water heater tank measured in gallons. Electric water heaters have rated volumes ranging from 30-gal to 120-gal, the gas-fired water heaters are rated from 30-gal to 100-gal, and oil-fired are 32-gal or 50gal. Figures B-1a and B-1b provide percentage breakdowns of sizes for electric and gasfired water heaters, respectively.

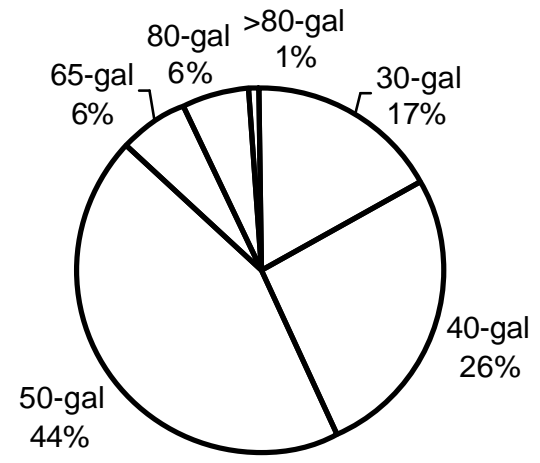

Figure B-1a Distribution of Electric Water Heaters by Rated Volume

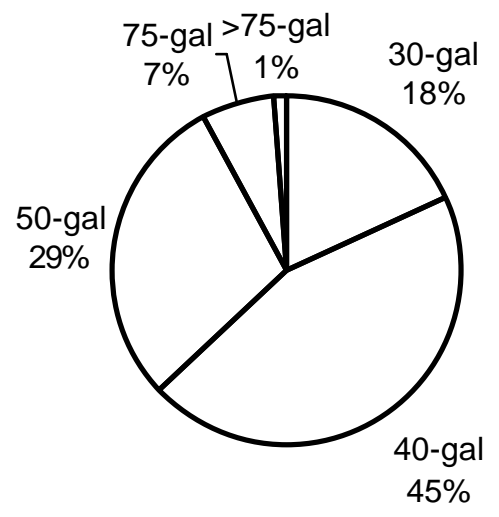

Figure B-1b Distribution of Gas-Fired Water Heaters by Rated Volume

It is important to note that each size category encompasses a range of water heater sizes. Table B-1 provides the rated volume categories and the sizes they include. For example, the rated volume of 30-gal for electric water heaters includes 28-gal and 30-gal and the rated volume for 40-gal includes of 38-gal and 40-gal water heater models. 


\begin{tabular}{|c|c|c|}
\hline Fuel Type & $\begin{array}{l}\text { Category } \\
\text { gallons }\end{array}$ & $\begin{array}{l}\text { Included Sizes in Database } \\
\text { gallons }\end{array}$ \\
\hline \multirow[t]{6}{*}{ Electric } & 30 & $\begin{array}{l}28 \\
30\end{array}$ \\
\hline & 40 & $\begin{array}{l}38 \\
40\end{array}$ \\
\hline & 50 & $\begin{array}{l}50 \\
52\end{array}$ \\
\hline & 65 & $\begin{array}{l}65 \\
66 \\
\end{array}$ \\
\hline & 80 & $\begin{array}{l}75 \\
80 \\
82 \\
\end{array}$ \\
\hline & $>80$ & $\begin{array}{l}85 \\
105 \\
119 \\
120\end{array}$ \\
\hline \multirow{5}{*}{ Gas-Fired } & 30 & 30 \\
\hline & 40 & $\begin{array}{l}38 \\
39 \\
40\end{array}$ \\
\hline & 50 & $\begin{array}{l}48 \\
50\end{array}$ \\
\hline & 75 & $\begin{array}{l}65 \\
75 \\
\end{array}$ \\
\hline & $>75$ & $\begin{array}{l}80 \\
100\end{array}$ \\
\hline
\end{tabular}

\section{B.2 Water Heaters by Manufacturer}

The collected data represent models from six manufacturers of electric water heaters and seven manufacturers of gas-fired water heaters. Only manufacturers whose water heaters were reported as being sold by the sources that provided data are included in the Price Information Table. For this reason, some manufacturers listed in the GAMA directory, such as Aero, Bock, Heat Transfer Products, and Vaughn, are not found in figures and tables presented in this document. These manufacturers are represented, however, in the Model Information Table.

Figures B-2a and B-2b show the percentages of the reported water heaters by manufacturer. 


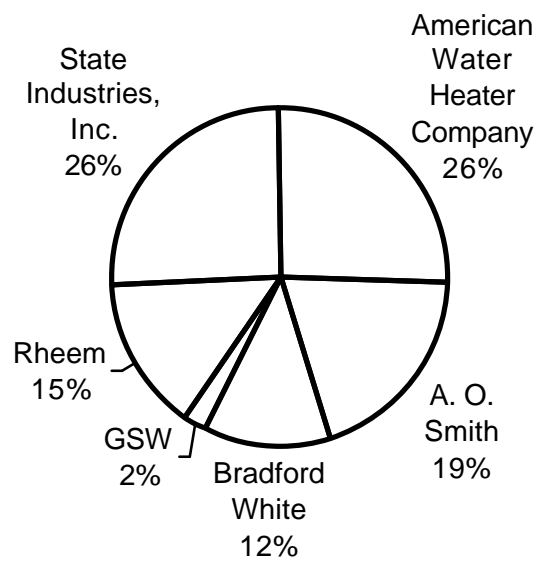

Figure B-2a Reported Electric Water Heaters by Manufacturer

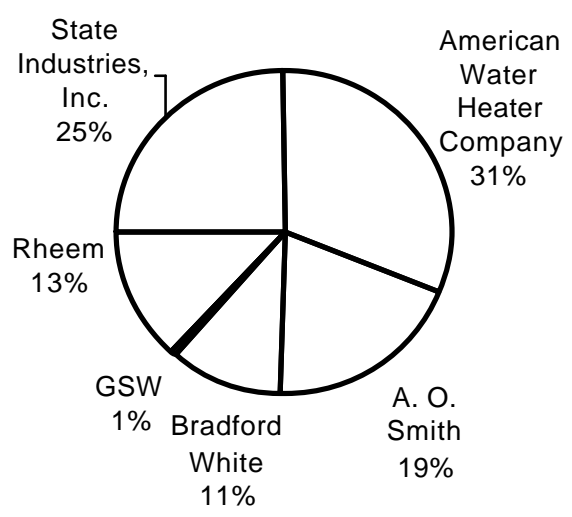

Figure B-2b Reported Gas-Fired Water Heaters by Manufacturer

\section{B.3 Water Heaters by Shape}

The water heater shape information is an important characteristic because, together with other data, it allows one to associate the water heaters with different installation configurations. Water heater shape designations vary according to manufacturer. Water heaters with different shape designations may have the same actual dimensions. Some manufacturers label water heater series or Afamilies@with shape names while some do not designate their water heaters as having a specific shape.

Nine shape designations are listed in the database for electric water heaters and eight are listed for gas-fired water heaters. A Blank designation has been assigned to water heaters with no reported shape designation. Tall water heaters account for the largest fraction of both electric and gas-fired water heaters sold.

Figures B-3a and B-3b provide breakdowns of shapes for electric and gas-fired water heaters, respectively. 


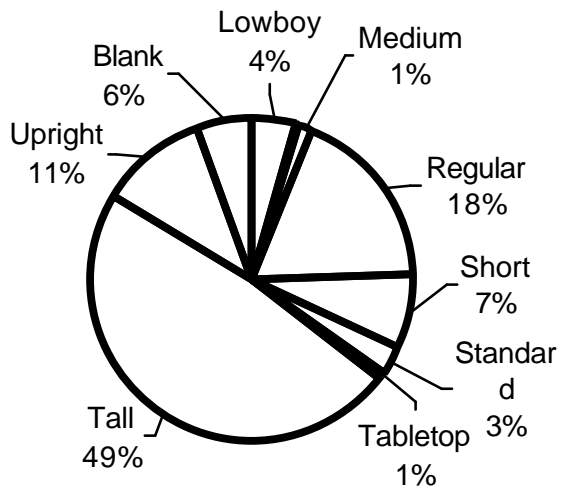

Figure B-3a Distribution of Electric Water Heaters by Shape

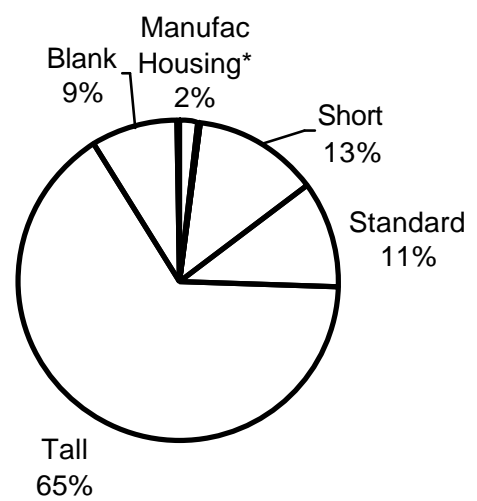

Figure B-3b Distribution of Gas-Fired Water Heaters by Shape

*Manufac. Housing = mobile home units

\section{B.4 Water Heaters by Insulation Thickness}

The jacket (sides and top) of water heaters are insulated with polyurethane foam or fiberglass. Most water heaters on the market today have at least 1 -in. $(2.5 \mathrm{~cm})$ thick foam insulation, while some manufacturers provide 2 -in. or 3 -in. $(5.1$ or $7.6 \mathrm{~cm})$ thick insulation. Insulation thickness levels are usually provided in manufacturer's literature and were otherwise obtained from their technical support hotlines.

Water heater insulation thickness varies between models and affects water heater efficiency. Manufacturers sometimes specify insulation thickness in inches and sometimes with an "R-value", which is a measure of the thermal resistance of the insulation. The Database lists insulation thickness in inches and in ranges from 1-in. to 3in., in quarter-inch increments. There are ten thickness designations listed in this table, including a ABlank@specification for those models for which no insulation thickness information was available. The electric water heaters are manufactured with insulation ranging from 1-in. $(2.5 \mathrm{~cm})$ to 3 -in $(7.6 \mathrm{~cm})$; most models have 2-in. $(5.1 \mathrm{~cm})$ of insulation. Gas-fired water heater models are available with insulation thicknesses of 1in. to 2.5 -in. $(6.3 \mathrm{~cm})$. Most gas-fired water heater models $(67 \%)$ are manufactured with 1-in. insulation.

Figures B-4a and B-4b provide the percentage breakdowns for reported water heaters by insulation thickness. 


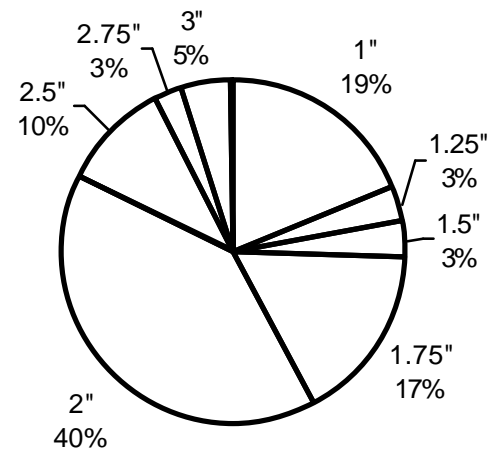

Figure B-4a Distribution of Electric Water Heaters by Insulation Thickness Feature

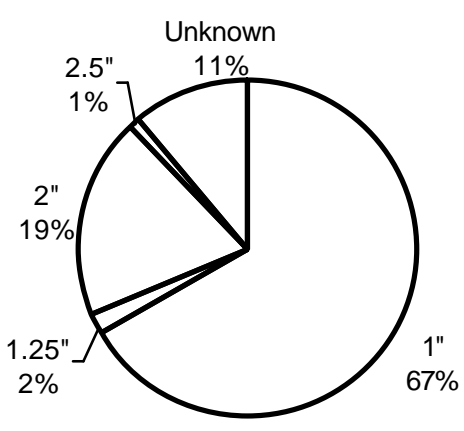

Figure B-4b Distribution of Gas-Fired Water Heaters by Insulation Thickness Feature

\section{B.5 Water Heaters by Heat Trap Option}

The database contains information about whether or not a listed water heater model is equipped with heat traps. Heat traps are devices that suppress the hot water convection in the pipe connections. They usually improve the energy efficiency performance of water heaters and are therefore an important design feature. Heat traps are a standard design feature of many models.

Figures B-5a and B-5b provide percentage breakdowns of water heaters by heat trap option for electric and gas-fired water heaters, respectively. True indicates that the designated water heaters are factory-equipped with heat traps. False indicates that the designated water heaters are not factory-equipped with heat traps. A No Info indicates that it is unknown whether or not the designated water heaters are equipped with heat traps; the information either was not reported or is not provided in product literature. A designation of False in the database does not indicate that a water heater is unable to support a heat trap; rather, it indicates that the water heater is not equipped with heat traps when it comes from the factory. The majority of water heater models reported for both fuel types are listed as not having factory-installed heat traps. In some cases, heat traps can be added during the site installation process. 


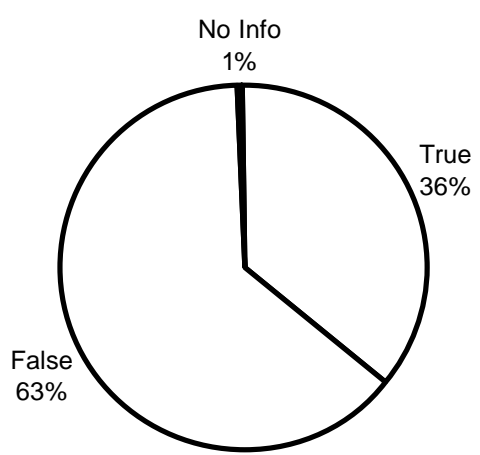

Figure B-5a Distribution of Electric Water Heaters by Heat Trap Option

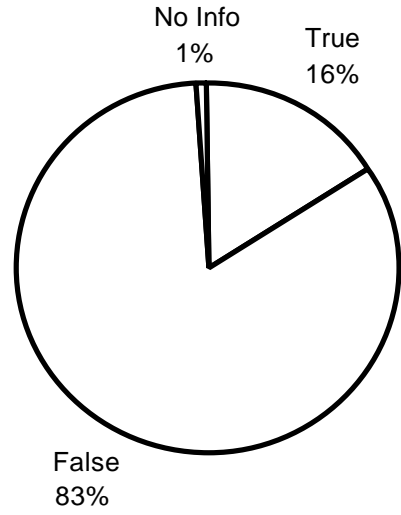

Figure B-5b Distribution of Gas-Fired Water Heaters by Heat Trap Option

\section{B.6 Water Heaters by Vent Type}

Some gas-fired water heaters are equipped with special vent design features, such as direct vents, power vents, through-the-wall vents, and side-wall vents as opposed to vents. As can be seen in Figure B-6, Standard vents dominate the gas-fired water heater market ( $86 \%$ of models).

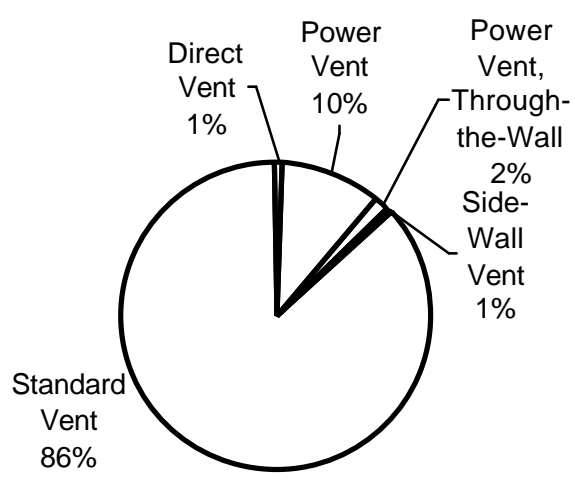

Figure B-6 Distribution of Gas-Fired Water Heaters by Vent Type

\section{B.7 Water Heaters by Electronic Ignition Feature}

Electronic ignition systems can replace standing pilots. The electronic ignition feature is only available for gas-fired water heaters. Figure B-7 displays percentages of reported gas-fired water heater models with the electronic ignition feature and those with a standing pilot. 


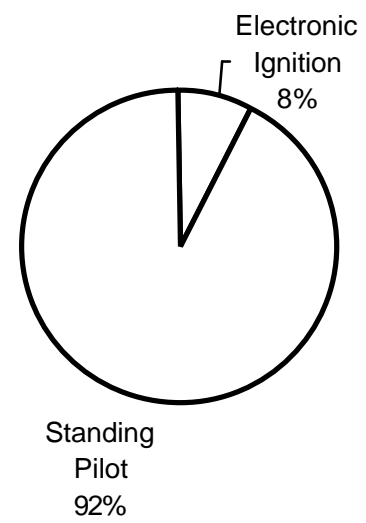

Figure B-7 Distribution of Gas-Fired Water Heaters by Electronic Ignition Feature

\section{B.8 Water Heaters by Length of Store Warranty}

Every water heater comes with a warranty, usually set by the manufacturer. Since the warranty period directly affects the cost of the water heater, distributors may sell water heaters with their own warranties. Figures B- $8 \mathrm{a}$ and B- $8 \mathrm{~b}$ provide percentages of reported water heater models by length of store warranty for electric and gas-fired water heaters, respectively.

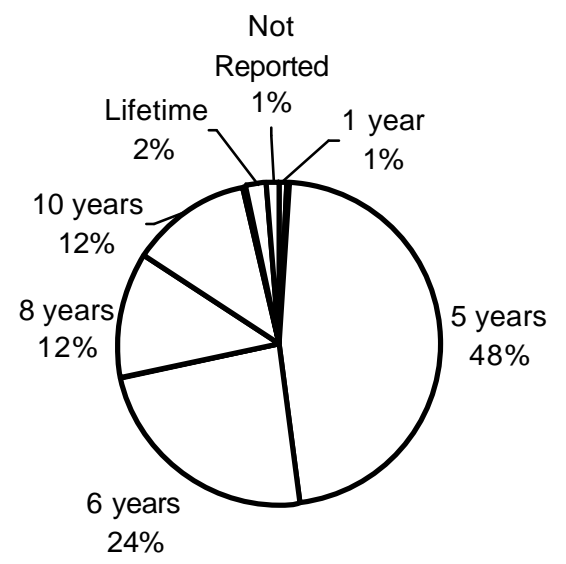

Figure B-8a Distribution of Electric Water Heaters by Length of Store Warranty (in Years)

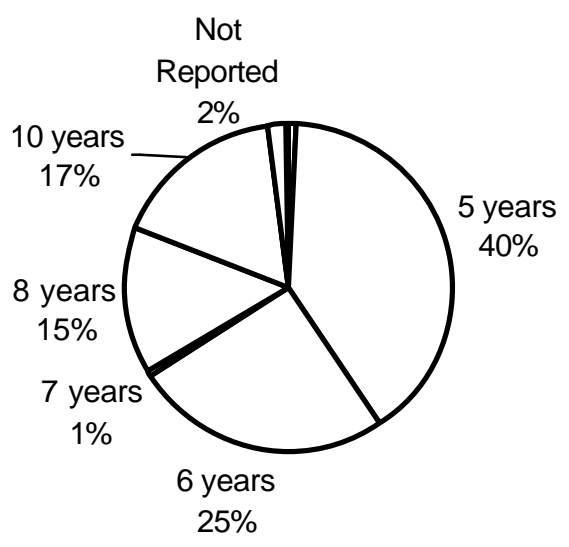

Figure B-8b Distribution of Gas-Fired Water Heaters by Length of Store Warranty (in Years)

\section{B.9 Water Heaters by Installation Cost}

Installation costs were collected simultaneously with retail price data. Five types of fees listed in the database constitute the installation costs used in the analysis: delivery fee, installation fee, removal fee, permit fee, and parts fee. The delivery fee is the cost to 
deliver the purchased water heater to the consumers home or building. The installation fee is the charge to the consumer to install the water heater. The removal fee is the charge to the consumer for removing an existing water heater and usually includes disposal of the removed water heater. The permit fee reflects the charge for a water heater installation permit. The parts fee is the fee charged to the consumer for parts provided by the installer. Each fee listed in the database refers to a charge set by the installation provider for the specific service provided. Some sources we contacted did not report fees, either because they do not offer the services that would result in fees or they include their fees in the retail price.

Of the stores that provided sales information on electric water heaters, $49.1 \%$ reported installation prices. Of those stores that provided sales information on gas-fired water heaters, $54.2 \%$ reported installation prices.

Figures B-9a and B-9b display the distribution of water heater models by fee type for electric and gas-fired water heaters, respectively.

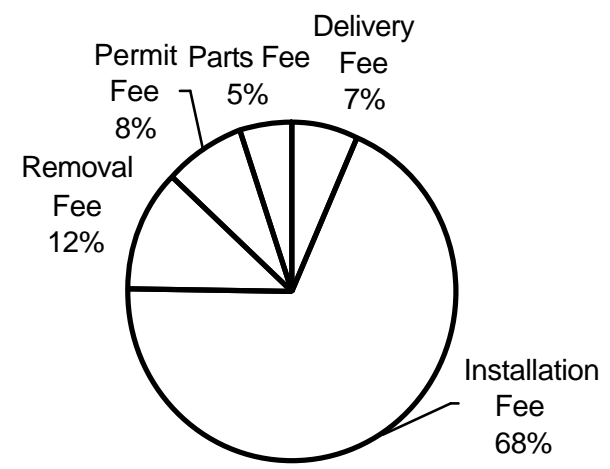

Figure B-9a Distribution of Electric Water Heaters by Fee Type

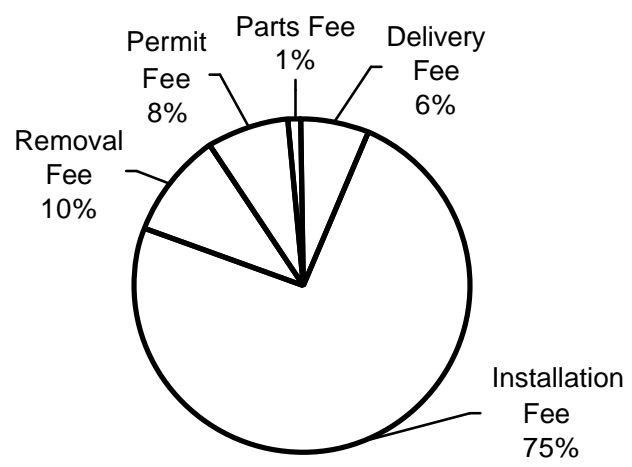

Figure B-9b Distribution of Gas-Fired Water Heaters by Fee Type 